\title{
HEALTH AND RETIREMENT EFFECTS IN A COLLECTIVE CONSUMPTION MODEL OF ELDERLY HOUSEHOLDS
}

Arthur Lewbel and Shannon Seitz

CRR WP 2011-4

Date Released: February 2011

Date Submitted: January 2011

\author{
Center for Retirement Research at Boston College \\ Hovey House \\ 140 Commonwealth Avenue \\ Chestnut Hill, MA 02467 \\ Tel: 617-552-1762 Fax: 617-552-0191 \\ http://crr.bc.edu
}

Arthur Lewbel is the Barbara A. and Patrick E. Roche chair in economics at Boston College (BC). Shannon Seitz is an assistant professor of economics at BC. The research reported herein was pursuant to a grant from the U.S. Social Security Administration (SSA) funded as part of the Retirement Research Consortium (RRC). The findings and conclusions expressed are solely those of the authors and do not represent the views of SSA, any agency of the federal government, the RRC, or BC.

(C) 2011, by Arthur Lewbel and Shannon Seitz. All rights reserved. Short sections of text, not to exceed two paragraphs, may be quoted without explicit permission provided that full credit, including (c) notice, is given to the source. 


\begin{abstract}
About the Sandell Grant Program
This paper received funding from the Steven H. Sandell Grant Program for Junior Scholars in Retirement Research. Established in 1999, the Sandell program's purpose is to promote research on retirement issues by scholars in a wide variety of disciplines, including actuarial science, demography, economics, finance, gerontology, political science, psychology, public administration, public policy, sociology, social work, and statistics. The program is funded through a grant from the Social Security Administration (SSA). For more information on the Sandell program, please visit our website at http://crr.bc.edu/opportunities/steven_h._sandell_ grant_program_2.html, send e-mail to crr@bc.edu, or call Marina Tsiknis at (617) 552-1092.
\end{abstract}

\title{
About the Center for Retirement Research
}

The Center for Retirement Research at Boston College, part of a consortium that includes parallel centers at the University of Michigan and the National Bureau of Economic Research, was established in 1998 through a grant from the Social Security Administration. The Center's mission is to produce first-class research and forge a strong link between the academic community and decision-makers in the public and private sectors around an issue of critical importance to the nation's future. To achieve this mission, the Center sponsors a wide variety of research projects, transmits new findings to a broad audience, trains new scholars, and broadens access to valuable data sources.

\author{
Center for Retirement Research at Boston College \\ Hovey House \\ 140 Commonwealth Avenue \\ Chestnut Hill, MA 02467 \\ Tel: 617-552-1762 Fax: 617-552-0191 \\ E-mail: crr@bc.edu \\ http://crr.bc.edu
}

\section{Affiliated Institutions:}

The Brookings Institution

Massachusetts Institute of Technology

Syracuse University

Urban Institute 


\begin{abstract}
Using data on older individuals and couples, we estimate a collective model of household consumption of a variety of goods, showing how resources are shared between husbands and wives, and how this allocation is affected by retirement and health status. We identify the extent to which shared consumption of goods by older married couples reduces the costs of living together relative to living alone. We also identify the fraction of household resources consumed by wives versus husbands, taking the jointness of some consumption into account. The results are relevant for household bargaining models and for a variety of welfare calculations.

Among other results, we find that older couples save between 24 and 40 percent on expenditures by sharing consumption of goods, that older wives consume between 30 and 42 percent of total household expenditures (taking sharing of goods into account), and that these shares are little affected by retirement, but increase dramatically when the husband's health is poorer.
\end{abstract}




\section{Introduction}

Much public policy research focuses on the living standards of the elderly, a group of particular concern because of the unique set of circumstances they face, including: (1) retirement and the decline in income that is typically associated with retirement, (2) declines in health status and increases in unanticipated medical expenses, and (3) illness and/or the death of a spouse.

The goal of this paper is to apply recent advances in the modeling of collective household behavior to the specifics of older households. In particular, we assess the living standards of individuals within households, and determine how those standards of living change with retirement, illness, and widowhood.

For an individual living alone, the link between consumption expenditures and attained standard of living is immediate; indeed, the latter is generally defined in terms of the former. But for a household, the connection is complicated by three factors: differences in preferences across household members, economies of scale in consumption, and the resource allocation across household members. By jointly consuming some goods (e.g., home heating or traveling together in the family car), a two-member household can attain a higher standard of living for its members than two individuals living alone with the same total income or expenditure level. Evaluating the standard of living of individuals within households therefore requires estimating the extent to which consumption goods and services are jointly consumed.

The standard of living within a household also depends on how the household's resources are allocated among household members. Previous work by Lise and Seitz (2011) using UK expenditure data highlights the fact that consumption inequality within households may be substantial: ignoring within household inequality underestimates the level of cross-sectional consumption inequality by 30 percent, as large differences in the earnings of husbands and wives translate into large differences in consumption allocations within households.

Household bargaining models suggest that allocations will depend at least in part on the relative incomes of husbands and wives (e.g. Becker, 1965, 1981). Since relative incomes generally change abruptly at retirement, one of our goals is to see how household resource shares change with retirement. The absolute and relative health of household members could also have a substantial impact on both the preferences and bargaining power of household members, and these effects are 
likely to be particularly important in older households.

The type of model we employ assumes a collective household that is characterised as a set of individuals, each of whom has a well defined objective function. The individuals then interact to generate household level decisions. We use the type of model in which information about individual household members is recovered from available household level consumption data. Examples include Chiappori (1988, 1992), Bourguignon and Chiappori (1994), Browning, Bourguignon, Chiappori, and Lechene (1994), Browning and Chiappori (1998), Vermeulen (2002), Browning, Chiappori, and Lewbel (2004), Lise and Seitz (2011), and Cherchye, De Rock, and Vermeulen (2008). These models are very useful because our available data on consumption decisions of older couples only contains consumption information on household level choices, while the objects of interest are based on the preferences of, and constraints faced by, the individuals who together make up the household.

Our specific analysis uses the model of Lewbel and Pendakur (2008) (which is in turn a simplified version of Browning, Chiappori and Lewbel 2004), suitably augmented to contain variables associated with health, retirement, and other attributes of older households. The advantages of this model for our application are that it has less intense data requirements (particularly regarding price data) relative to most other models in this literature, and it delivers estimates of the resource shares and relative standards of living that are the goal of our analysis. Our results extend these earlier collective model papers in directions of particular importance to the study of retirement and aging, and in particular we focus on the roles of health status and retirement.

Declines in health status are an inevitable part of the aging process and interact in important ways with household consumption behavior. Previous research indicates that out-of-pocket medical expenses can be substantial, even for those with health insurance (French and Jones, 2004; Feenberg and Skinner, 1994; Palumbo, 1999). Palumbo (1999) estimates that roughly 10 percent of older households spend 20 percent or more of their income on out-of-pocket medical expenses, not including nursing home expenditures. We allow health status to affect both economies of scale in consumption as well as the allocation of resources between husbands and wives.

Evidence from previous research indicates that expenditure patterns tend to change at retirement and that retirement is a household and not an individual decision (Banks, Blundell, and Casanova Rivas, 2007; Blau, 1998; Blau and Gilleskie, 2006; Gustman and Steinmeier, 2000; 
Hurd, 1990; Michaud and Vermeulen, 2004). In this paper we allow age and retirement to affect the allocation of resources (potentially via bargaining power) and jointness of consumption in two person households.

A limitation of our empirical model is that it is static, and so does not measure dynamic and forward looking implications of retirement and health declines on welfare and consumption allocations. Our results condition on health and retirement status at the moment, and so cannot be used to address issues such as when individuals within households choose to retire, or how they choose to allocate their savings over time. We assume a time separable model and focus on the allocation of household's consumption expenditures within a time period, rather than over time. This simplification allows us to make use of cross section or short panel data while still addressing many fundamental questions of interest.

Using our model, the types of questions we address in this analysis are: To what extent does joint consumption increase following retirement or changes in the health status of one or both spouses? How does the allocation of resources to husbands versus wives change with illness and retirement? What are the costs of maintaining a fixed standard of living when a spouse dies? Many policy and welfare calculations depend on answering these questions correctly. These results should be useful for constructing poverty lines for the older, for determining appropriate levels of social and private insurance, for indexing welfare, pension, or social security payments, and for calculating appropriate measures of welfare inequality in the older population.

\section{Data Summary}

The data consist of characteristics of one- and two-person households around the age of retirement in the U.S. Health and Retirement Study (HRS) and a supplement to the HRS, the Consumption and Activities Mail Survey (CAMS). The HRS contains demographic information, comprehensive information on retirement and health status, as well as detailed income data. The CAMS contains data on total annual household expenditures, as well as expenditure data for a set of 38 consumption goods and data on 33 different activities.

In this paper we use data from the 2005 and 2007 waves of the HRS/CAMS. The sample is restricted to married couples and widows/widowers between ages 50 and 80 . We also exclude 
households in the bottom and top 5 percent of the total expenditure distribution. Our remaining sample consists of 1004 married couples, 420 widows, and 79 widowers. The demographic characteristics are summarized in Table 1. Relative to one person households, married couples are much more likely to be college educated and in good health. Widows tend to be older and are more likely to be retired than singles and married couples.

We consider ten expenditure categories: groceries, restaurant meals, gasoline, personal care, clothing, vacation, utilities, garden supplies and services, car maintenance, and home maintenance. In Table 2 we first document the distribution of expenditures across household type. Interesting expenditure patterns across gender emerge from the data: women tend to spend more on clothing, gardening, and personal care while men tend to have higher expenditures on restaurant meals and gasoline.

Married couples and widows appear to devote a larger share of their budgets to groceries and home maintenance. As expected, married couples in particular spend more on vacations and less on utilities relative to single person households. In Table 3, we consider how budget shares for married couples differ conditional on the retirement status of each spouse. In general, expenditures on items related to work or transportation (restaurant meals, gasoline, personal care, clothing, car maintenance) tend to be higher in households where at least one spouse is not retired and expenditures related to home production (groceries, gardening) and leisure (vacations) tend to be higher in households in which at least one spouse is retired.

Finally, consider the way budget shares vary with health status in married couples. We use qualitative information on self-reported health to measure health status in our empirical exercise. The HRS contains the following question: "Would you say your health is excellent, very good, good, fair, or poor?" which will be used to construct our preliminary measure of health status. This or similar measures have been used in previous studies (Palumbo, 1999; De Nardi, French, and Jones, 2006). Wallace and Herzog (1995) provide a comprehensive review of the health information available in the HRS. In Table 4 we document the distribution of expenditures in married couples by the health status of each spouse. In general, households devote a higher share of expenditures to groceries, gasoline, and utilities and a lower share to restaurants and vacations when either spouse is in poor health, suggesting spouses may be spending more time at home. When the husband is in poor health, households tend to spend slightly more on personal care and clothing 
(goods that single women tend to spend relatively more on) and when the wife is in poor health households tend to spend more on car maintenance (a good single men tend to spend relatively more on).

\section{Resource Shares and Indifference Scales}

Two attributes of collective households that we will be identifying and estimating are resource shares and indifference scales, as defined in Browning, Chiappori, and Lewbel (2004). For a couple, let $q_{f}$ and $q_{m}$ be consumption bundles, i.e., $K$ vectors of quantities of goods and services consumed by the wife and by the husband, respectively. If market prices of the goods and services are given by the $K$ vector $p$, then define the wife's resource share $\eta$ by $\eta=p^{\prime} q_{f} /\left(p^{\prime} q_{f}+p^{\prime} q_{m}\right)$, so the resource share $\eta$ is the fraction of total resources that are devoted to the wife, with the fraction $1-\eta$ being the husband's resource share.

As will be discussed more fully in the next section, the total bundle $q$ of goods and services

purchased by the household will in general be smaller than (rather equal to) $q_{f}+q_{m}$, because some goods may be consumed jointly, resulting in economies of scale in consumption. In particular, for goods that are publicly consumed within the household, like heat, the quantity consumed can equal up to twice the amount purchased, since each household member can consume up to the total amount purchased. Let total household expenditures be $x=p^{\prime} q$. Because of jointness of consumption $x$ can be less than, rather than equal to $p^{\prime} q_{f}+p^{\prime} q_{m}$. For internal consistency, resource shares are defined in terms of fractions of the latter, rather than as fractions of $x$. We will be interested in estimating these resource shares as measures of inequality within a household. Browning, Chiappori, and Lewbel (2004) show that, using this definition, resource shares are monotonically increasing in Pareto weights, and so in bargaining models $\eta$ can be interpreted as a measure of the relative bargaining power of the wife.

Unlike resource shares, which compare the wife to the husband, indifference scales are welfare measures that compare the same individual in two different situations; living alone versus with a spouse. An indifference scale $I_{j}$ of an individual $j$ is defined as follows.

First consider a woman living with a husband, where the couple has a total expenditure level $y$ and faces prices $p$. She consumes the bundle $q_{f}$, which is determined by some household decision 
making process, and so attains a utility level $U_{f}\left(q_{f}\right)$, where $U_{f}$ is her utility level over goods. Note that $q_{f}$ will depend in part on her resource share within the household, and on the extent to which consumption in the household is joint. Now suppose she lived alone instead of with a spouse. Let $y_{j}$ be the total expenditure level she would require at prices $p$ to buy a bundle $\widetilde{q}_{f}$ that gives her the same utility as $q_{f}$, so $U_{f}\left(q_{f}\right)=U_{f}\left(\widetilde{q}_{f}\right)$. Then her indifference scale (at total expenditure level $y$ and prices $p$ ) is defined as $I_{f}=y_{j} / y$.

In short, the indifference scale $I_{f}$ is the fraction of the couple's income $y$ that she would need, if living alone, to attain the same level of utility from consumption that she obtains from living with a partner. Indifference scales differ from ordinary adult equivalence scales (see Lewbel 1997 for a survey) in that equivalence scales equate the utility of an individual to the utility of a household, and so suffer from fundamental identification problems associated with interpersonal comparisons of utility. In contrast, indifference scales are invariant to how utility is cardinalized. Specifically, replacing $U_{f}\left(q_{f}\right)$ with any monotonic transformation of her utility function leaves the indifference scale unchanged.

As a result, unlike equivalence scales, indifference scales can at least potentially be identified just from revealed preference data. Intuitively, the reason for this difference is that equivalence scales compare the utility of two different entities, namely, an individual and a household. In contrast, indifference scales compare the same individual in two different settings, i.e., living alone facing market prices, versus living in a household, consuming his/her share of the household's resources and facing shadow prices.

Indifference scales are particularly well suited for assessing the welfare impacts of widowhood, since they describe exactly in percentage terms how much income the surviving wife can afford to lose as a result of the spouse's death, without a reduction in her standard of living.

\section{The Model}

We apply the model of Lewbel and Pendakur (2008), which is itself a restricted version of the household consumption model of Browning, Chiappori, and Lewbel (2004). This restriction permits the use of cross section data without price variation, of the type we have available in the HRS. 
In our application of their model, consider households of three types: single women (specifically widows), single widower men, and married older couples. Index the members of the household by $j=f$ (female) and $j=m$ (male). Let $z_{j}$ denote a vector of observed demographic characteristics for each individual, which includes their health and retirement status, among other attributes. The individual has a utility function $U_{j}\left(q, z_{j}\right)$, which denotes the utility he or she gets from consuming a bundle (a $K$ vector) of quantities of goods $q$. Individuals are assumed to all be facing the same vector of prices $p$ for goods and services.

Consider the behavior of singles first. An individual $j$ having total expenditures $y$ will choose to consume a bundle $q_{j}\left(p, z_{j}\right)$ obtained by maximizing $U_{j}\left(q_{j}, z_{j}\right)$ subject to the budget constraint $y=p^{\prime} q_{j}=\sum_{k=1}^{K} p^{k} q_{j}^{k}$. Let $w_{j}^{k}\left(y, z_{j}\right)=p^{k} q^{k}\left(p, z_{j}\right) / y$ denote the resulting fraction of total expenditures $y$ that the individual spends on $\operatorname{good} k$, so $w_{j}^{k}$ is a budget share. Since all consumers face the same prices, $p$ is a constant that we have dropped from $w_{j}^{k}\left(y, z_{j}\right)$. The function $w_{j}^{k}\left(y, z_{j}\right)$ is therefore a budget share Engel curve, that is, a Marshallian demand function, in budget share form, evaluated at a fixed price vector.

Now consider couples. A couple or household $h$ consists of two individuals, having utility functions $U_{f}$ and $U_{m}$ respectively. In addition to the attributes $z_{f}$ and $z_{m}$ of its members, the household $h$ may be characterized by an additional vector of household attributes $z_{h}$. These $z_{h}$ may affect how the household allocates resources among its members. A household $h$ is also assumed to have a diagonal $K$ by $K$ matrix $A_{h}$ that summarizes the extent to which each good can be jointly consumed. The element $A_{h}^{k}$ in the $k^{\prime} t h$ row and column of $A_{h}$ is the Barten (1964) scale for $\operatorname{good} k$. The idea is that a household that purchases a quantity $q^{k}$ of good $k$ can act as if it had actually purchased the quantity $q^{k} / A_{h}^{k}$ of the good, and so the wife can consume a quantity $q_{f}^{k}$ and husband a quantity $q_{m}^{k}$, where $q_{f}^{k}+q_{m}^{k}=q^{k} / A_{h}^{k}$. Each $A_{h}^{k}$ is a number between one half and one, where the closer the number is to one, the less the good is jointly consumed. A purely private good $k$ would have $k=1$. In the full Browning, Chiappori, and Lewbel (2004) model, price variation is exploited to estimate these Barten scales along with the rest of the model. In our cross section framework we will only be able to identify some useful summary measures of economies of scale in consumption, but not the individual $A_{h}^{k}$ parameters.

The couple chooses consumption quantities $q_{f}$ and $q_{m}$ to maximize

$$
V\left(U_{f}\left(q_{f}, z_{f}\right), U_{m}\left(q_{m}, z_{m}\right), p, y, z_{h}\right)
$$


where $V$ may be a social welfare function, or bargaining function, or any other function that is strictly increasing in $U_{f}$ and $U_{m}$ and so yields a Pareto efficient allocation of resources within the household. In addition to depending on the utility of household members, $V$ may also directly depend on variables like $z_{h}$. So, e.g., in a bargaining model $z_{h}$ could include the relative wages of the husband and wife, which could in turn affect the allocation of resources within the household through the function $V$.

The household having total expenditures $y$ chooses a purchased quantity vector $q$ and associated consumption quantity vectors $q_{f}^{k}$ and $q_{m}^{k}$ to maximize $V$ subject to the consumption technology (economies of scale) constraint $q_{f}+q_{m}=A_{h}^{-1} q$ and the budget constraint $p^{\prime} q=y$. Lewbel and Pendakur (2008) show that, given some restrictions on the function $V$, couples will choose to purchase budget shares given by

$$
w_{h}^{k}(y, z)=\eta(z) w_{f}^{k}\left(\frac{\eta(z) y}{\delta_{f}\left(z_{f}\right)}, z_{f}\right)+[1-\eta(z)] w_{m}^{k}\left(\frac{[1-\eta(z)] y}{\delta_{m}\left(z_{m}\right)}, z_{m}\right)
$$

for each good $k$, where $z$ is the union of the elements of the vectors $z_{f}, z_{m}$, and $z_{h}, \eta(z)$ is the fraction of the household's resources (total expenditures) that are allocated to the wife, and $\delta_{f}\left(z_{f}\right)$ and $\delta_{m}\left(z_{m}\right)$ are functions associated with the economies of scale associated with joint consumption in the household. Note that both $\eta(z)$ and $\delta_{j}(z)$ implicitly depend upon $A_{h}$ and $p$. In this model, Lewbel and Pendakur (2008) show that indifference scales are given by $I_{f}(z)=\delta_{f}\left(z_{f}\right) / \eta(z)$ and $I_{m}(z)=\delta_{m}\left(z_{m}\right) /[1-\eta(z)]$. These indifference scales embody both the economies of scale and resource allocations associated with being married versus single.

A key identifying assumption in the Lewbel and Pendakur (2008) and Browning, Chiappori, and Lewbel (2004) model is that the utility functions $U_{f}$ and $U_{m}$, denoting the tastes of women and men, are the same whether they live alone or in couples, so that the differences in purchasing patterns between singles and couples are entirely due to jointness of consumption of some goods (economies of scale to consumption) and to resource allocations between husband and wife. This restriction can be relaxed in these models by observing expenditure allocations across goods within households, or by functional form restrictions on any utility changes that occur with marriage. However, in the present context we deal with this issue by restricting attention to singles who are widows or widowers. Unlike people who are single by choice, those individuals chose to marry, and so presumably have the same tastes on average as married individuals. 
Following Lewbel and Pendakur (2008), we choose functional forms for utility that yield budget shares for singles $w_{j}^{k}\left(y, z_{j}\right)$ of the form

$$
w_{f}^{k}=a_{f}^{k 0}+a_{f}^{k \prime} z_{f}+\left(\ln y-e_{f}^{\prime} z_{f}\right) b_{f}^{k}+\left(\ln y-e_{f}^{\prime} z_{f}\right)^{2} c_{f}^{k}+\varepsilon_{f}^{k}
$$

for women and

$$
w_{m}^{k}=a_{m}^{k 0}+a_{m}^{k \prime} z_{m}+\left(\ln y-e_{m}^{\prime} z_{m}\right) b_{m}^{k}+\left(\ln y-e_{m}^{\prime} z_{m}\right)^{2} c_{m}^{k}+\varepsilon_{m}^{k}
$$

for men, for each good $k=1, \ldots, K$. Here the parameters $a_{j}^{k 0}, b_{j}^{k}$, and $c_{j}^{k}$ are scalar constants to be estimated (using data from widows and widowers) for each good $k$ and gender $j$, while $a_{j}^{k}$ and $e_{j}$ are constant parameter vectors to be estimated. The constraint that budget shares sum to one imposes the restrictions that, for each $j, \sum_{k=1}^{K} a_{j}^{k 0}=1, \sum_{k=1}^{K} b_{j}^{k}=0, \sum_{k=1}^{K} c_{j}^{k}=0$, and $\sum_{k=1}^{K} a_{j}^{k}$ equals a vector of zeros.

These budget shares correspond to a rank three demand system (see Lewbel 1997) that is quadratic in log total expenditures, which many authors have found provide a good fit for Engel curves (see, e.g., Banks, Blundell, and Lewbel 1997), and are a quadratic in demographic characteristics that is restricted to satisfy shape invariance, which is also known to fit well empirically (see, e.g., Blundell, Duncan and Pendakur 1998).

For couples, we again follow Lewbel and Pendakur (2008) and specify the resource sharing rule $\eta(z)$ and the $\log$ of the economies of scale functions $\delta_{j}\left(z_{j}\right)$ as linear in $z$, so

$$
\eta(z)=r^{\prime} z=r_{0}+r_{h}^{\prime} z_{h}+r_{m}^{\prime} z_{m}+r_{f}^{\prime} z_{f}
$$

and

$$
\ln \delta_{j}\left(z_{j}\right)=d_{0 j}+d_{j}^{\prime} z_{j}
$$

for $j=f, m$, where $r_{0}, d_{0 f}$, and $d_{0 m}$ are constant scalar parameters and $d_{f}, d_{m}, r_{h}, r_{m}$, and $r_{f}$ are constant parameter vectors. Pulling together these expressions yields budget share demand 
functions for couples having the functional form

$$
\begin{aligned}
w_{h}^{k}= & \left(r^{\prime} z\right)\left(a_{f}^{k 0}+a_{f}^{k \prime} z_{f}\right. \\
& +\left(\ln y+\ln \left(r^{\prime} z\right)-d_{0 f}-d_{f}^{\prime} z_{f}-e_{f}^{\prime} z_{f}\right) b_{f}^{k} \\
& \left.+\left(\ln y+\ln \left(r^{\prime} z\right)-d_{0 f}-d_{f}^{\prime} z_{f}-e_{f}^{\prime} z_{f}\right)^{2} c_{f}^{k}\right) \\
& +\left(1-r^{\prime} z\right)\left(a_{m}^{k 0}+a_{m}^{k \prime} z_{m}\right. \\
& +\left(\ln y-\ln \left(1-r^{\prime} z\right)-d_{0 m}-d_{m}^{\prime} z_{m}-e_{m}^{\prime} z_{m}\right) b_{m}^{k} \\
& \left.+\left(\ln y-\ln \left(1-r^{\prime} z\right)-d_{0 m}-d_{m}^{\prime} z_{m}-e_{m}^{\prime} z_{m}\right)^{2} c_{m}^{k}\right)+\varepsilon_{h}^{k}
\end{aligned}
$$

for $k=1, \ldots, K$. These also imply functional forms for the indifference scales given by

$$
\ln I_{f}(z)=d_{0 f}+d_{f}^{\prime} z_{f}-\ln \left(r^{\prime} z\right)
$$

and

$$
\ln I_{m}(z)=d_{0 m}+d_{m}^{\prime} z_{m}-\ln \left(1-r^{\prime} z\right)
$$

The entire model consists of estimating equation (1) for each good $k=1, \ldots, K$ using data from widows, equation (2) for each good $k$, using data from widowers, and equation (5) for each good $k$ using data from married couples. All these equations need to be estimated simultaneously, both because the errors $\varepsilon_{f}^{k}, \varepsilon_{m}^{k}$, and $\varepsilon_{h}^{k}$, will in general be correlated across goods $k$, and because many of the same parameters appear in multiple equations.

As described earlier, our sample is restricted to married couples and widows/widowers between ages 50 and 80, and we consider $K=10$ expenditure categories: groceries, restaurant meals, gasoline, personal care, clothing, vacation, utilities, garden supplies and services, car maintenance, and home maintenance (home repairs, supplies, and services). The characteristics $z$ that we include in the model are age minus 60, self-reported health status, retirement status, and education.

The data are constructed so that $z=0$ in the benchmark specification corresponds to a couple with a mean female income contribution and in which both spouses are still working, in good health, and 60 years old. As a result, in our tables the reported value of $r_{0}$ will equal the resource share $\eta$ for this group, and similarly for other subscript zero coefficients. 


\section{Results}

The estimation results for four specifications of the model are presented in Table 5 and Table 6 . The joint system we estimate consists of the vectors of budget shares for widows, for widowers, and for couples. For efficiency, these are all estimated simultaneously, since all the parameters in the widow and widower models also appear in the couple model. We estimate the joint system by nonlinear seemingly unrelated regression.

Our benchmark specification, which allows both scale economies and the sharing rule to vary with age and the health and retirement status of each spouse, is presented in Column 1. To measure how allocation of resources among household members is affected by the amount each spouse contributes to the household income, the sharing rule further includes the percentage of household income that is earned by the wife. For comparison purposes, the specification in Column 2 allows both scale economies and the sharing rule to vary with education instead of age of each spouse. In Column 3 we report estimates of the benchmark model including data on all singles, not just widows and widowers. Finally, Column 4 contains estimates of a version of the benchmark model where the budget share for medical expenditures is incorporated.

The scale economy parameters are expected to yield values of $\delta_{f}$ and $\delta_{m}$ that lie between onehalf (complete sharing) and one (no sharing). The scale economy for couples in which the husband is still in the labor force and in good health is $\delta_{m}=0.76$. In other words, the shadow price faced by married couples is associated with a cost-of-living index which is 76 percent of the costs faced by single men. When the husband is in poor health, the scale economy is 0.69 . For wives, the corresponding scale economies are 0.61 and 0.59. Consistent with Lewbel and Pendakur (2008), these estimates show that men face smaller scale economies than women, that is, a lower fraction of what men consume is shared with their spouse. We also find that for men and women, the estimated scale economies are higher for individuals in poor health.

The estimated resource shares are comparably small. The wife's share of household consumption is 33 percent in a couple with a mean female income contribution and in which both spouses are still working, in good health, and 60 years old. The resource shares also appear to be quite sensitive to the health status of the husband. When her husband is in poor health, the wife's share rises to 48 percent. In contrast to these health effects of the husband, resource shares seem largely 
unaffected by the wife's health status, and by the retirement status of either spouse. The contribution of women to household income raises her share significantly, while the age of both spouses affects their sharing rule negatively.

The resource shares we find for married women are smaller than those typically reported in the literature. For example, Lewbel and Pendakur (2008) report wives' resource shares of between 0.36 and 0.46 using the same estimation method. Lise and Seitz (2011) report resource shares averaging of 40 percent, while others report estimates near 0.5 (e.g., Cherchye, De Rock, and Vermeulen, 2008) and higher (Browning, Chiappori, and Lewbel, 2004). These other papers focus on working-age populations, so it is possible that women in our older households receive lower shares, perhaps revealing a decrease in bargaining power with age.

The specification in Column 2 allows both scale economies and the sharing rule to vary with education (dummy variable for college educated or not) instead of age of each spouse. The estimated resource share in a couple with a mean female income contribution and in which both spouses are still working, in good health, and 60 years old is similar to the benchmark. The economies of scale, however, are slightly larger for both men and women relative to the benchmark. College education lowers the scale economies of both spouses significantly. The sharing rule, on the other hand, does not differ by education level.

Our base model was estimated using couples along with widows and widowers, but excludes divorced and never married single men and women, because divorced and never married individuals could have preferences over goods that differ from those who chose to not marry or to end marriages. As a robustness check and to evaluate the importance of selection into marriage, Column 3 includes data on all single individuals in the data, instead of just widows and widowers. Differences between these estimates and the previous columns could arise due to differences in the preferences of widows and widowers versus other single women and men, or because of efficiency gains resulting from the use of a larger sample. The estimated economies of scale for healthy men (0.79) and healthy women (0.61) who are working and 60 years old are lower than in the benchmark specification. The other estimates seem quite stable relative to the benchmark. The resource shares are smaller than in the benchmark specification: The wife's share of household income is 31 percent in a couple with a mean female income contribution and in which both spouses are still working, in good health and 60 years old. The female income contribution has a significantly pos- 
itive effect on wife's share. Furthermore, a wife's share is significantly increased by her husband's poor health and decreased by her own poor health.

With an average of 19 percent, medical expenditures are a large part of an older household's budget. We therefore estimate a version of the model in which medical expenditures are included in the vector of budget shares in estimation in Column 4 (we do not use this case as our benchmark because medical expenditures suffer from measurement error issues associated with differences between actual consumption versus expenditures on insurance and copayments for service). Including medical expenditures, the estimated wives' resource share in a couple with both spouses working, in good health, and 60 years old is larger than the benchmark. However, the wife's resource share is now significantly lower when she is in poor health or when her husband is retired. For women, a poor health status also has a significant effect on their scale economies. The economies of scale for healthy men who are not yet retired and 60 years old are again smaller than for women, and men's economies of scale are significantly smaller when they are retired or in poor health. Other estimates are similar to the benchmark case.

\section{Conclusions}

We estimate the extent to which joint consumption of some goods reduces the costs of living for older couples versus living alone. We also estimate the fraction of household resources that are consumed by wives versus husbands, taking this jointness of some consumption into account. We show how these numbers are affected by the health and retirement status of each household member.

We find that older wives typically consume between 30 and 42 percent of total household expenditures (taking joint consumption and sharing of goods into account). These shares are somewhat lower than what other researchers using similar methodologies have reported for younger couples. We find these shares are not affected much by retirement decisions, but wives shares increase substantially, up to 48 percent, when the husband's health is poorer. This increase in shares is consistent with the interpretation of resource shares as a measure of relative bargaining power within a household.

As for economies of scale to consumption, we find that by sharing consumption with his wife, 
husbands only need to spend 76 cents for every dollar they would spend while living alone to attain the same indifference curve over goods. This drops to 69 cents for men in poor health. For wives, the corresponding number is near 60 cents regardless of health. So while wives get less than half of the couples's resources, each dollar they do get allows them to buy more of what they consume (relative to having the same resources when single) than each dollar their husband gets. Essentially, this means that shared goods comprise a higher fraction of wife's consumption than of husband's consumption.

Dividing each household member's economies of scale measure by their resource shares yields that person's indifference scale. So for example a wife having a .35 resource share and .6 cost of living index has an indifference scale of $.35 / .6=.58$, meaning that this woman would require 58 percent of the household's income to attain the same standard living if she were living alone that she attains as a member of the couple. In contrast, a healthy older man living alone would require 86 percent $(.65 / .76=.86)$ of a couple's total expenditures to attain the same standard of living he enjoys while married. This difference between men and women is largely due to the husband consuming much more of the household's resources than the wife, though that is partly offset by the wife's greater benefit from sharing goods. These differences would be directly relevant for marriage bargaining models that are based on each member's outside option.

One useful area for future research would be incorporating time use into the model, because time use is a substitute for some forms of consumption (e.g., home cooking versus purchase of prepared foods) and a complement to others (e.g., vacations), and because availability and allocation of time use can be dramatically affected by changes in health and retirement status of both oneself and one's spouse.

A second useful extension would be to nest this paper's model into a dynamic context, to permit analysis of the timing of allocation issues, and the role of consumption smoothing over the latter part of the life cycle. The types of intrahousehold allocations we identify could also be relevant for determining the savings levels of each household member, and likely impacts the timing of retirement decisions. 


\section{References}

Banks, J., R. Blundell, and M. Casanova Rivas (2007): “The dynamics of retirement behavior in couples: Reduced-form evidence from England and the US," Mimeo, University College London (UCL).

Banks, J., R. Blundell, and A. Lewbel, (1997): "Quadratic Engel curves and consumer demand," Review of Economics and Statistics, 79, 527-539.

Barten, A.P. (1964): "Family composition, prices, and expenditure patterns," in Econometric Analysis for National Economic Planning: 16th Symposium Colston Society, P. Hart, G. Mills, and J. K. Whitaker, eds., 277-292, London: Butterworth.

Becker, G.S. (1965): “A Theory of the Allocation of Time,” Economic Journal, 75, 493-517.

Becker G.S. (1981): “A Treatise on the Familiy,” Cambridge, Mass.: Harvard University Press.

Blau, D. (1998): "Labor force dynamics of older married couples," Journal of Labor Economics, 16, 595-629.

Blau, D. and D. Gilleskie (2006): "Health insurance and retirement of married couples," Journal of Applied Econometrics, 21, 935-953.

Blundell, R., A. Duncan, and K. Pendakur (1998): "Semiparametric estimation and consumer demand," Journal of Applied Econometrics, 13, 435-461.

Bourguignon, F., M. Browning, P.-A. Chiappori, and V. Lechene (1994): "Incomes and outcomes: a structural model of intra-household allocation," Journal of Political Economy, 102, 10671096.

Bourguignon, F. and P.-A. Chiappori (1994): "The collective approach to household behaviour," in The Measurement of Household Welfare, R.W. Blundell, I. Preston, and I. Walker, eds., 70-85, Cambridge University Press.

Browning, M. and P.-A. Chiappori (1998): "Efficient intra-household allocation: a characterisation and test," Econometrica, 66, 1241-1278.

Browning, M., P.-A. Chiappori, and A. Lewbel (2004): "Estimating Consumption Economies of Scale, Adult Equivalence Scales, and Household Bargaining Power,” Boston College Working Papers in Economics 588.

Cherchye, L., B. De Rock, and F. Vermeulen (2008): "Economic well-being and poverty among 
the elderly: An analysis based on a collective consumption model," IZA Discussion Papers 3349.

Chiappori P.-A. (1988): “Rational household labor supply,” Econometrica, 56, 63-89.

Chiappori P.-A. (1992): “Collective labour supply and welfare,” Journal of Political Economy, $102,437-467$.

De Nardi, M., E. French, and J.B. Jones (2006): "Differential mortality, uncertain medical expenses, and the saving of elderly singles," NBER Working Papers 12554, National Bureau of Economic Research, Inc.

Feenberg, D. and J. Skinner (1994): "The risk and duration of catastrophic health care expenditures," The Review of Economics and Statistics, 76, 633-647.

French, E. and J. Jones (2004): "The effects of health insurance and self-insurance on retirement behavior," Center for Retirement Research Working Paper, 2004-12, Boston College.

Gustman, A. and T. Steinmeier (2000): "Retirement in dual-career families: A structural model," Journal of Labor Economics, 18, 503-545.

Hurd, M. (1990): "Research on the elderly: economic status, retirement, and consumption and saving," Journal of Economic Literature, 28, 565-637.

Lewbel, A. (1997): “Consumer Demand Systems and Household Equivalence Scales,” Handbook of Applied Econometrics, Volume II: Microeconomics, M. H. Pesaran and P. Schmidt, eds., Oxford: Blackwell Publishers Ltd.

Lewbel, A. and K. Pendakur (2008): "Estimation of Collective Household Models With Engel Curves," Journal of Econometrics, 147, 350-358.

Lise, J. and S. Seitz (2011): “Consumption Inequality and Intra-Household Allocations,” Review of Economic Studies, forthcoming.

Michaud, P. and F. Vermeulen (2004): "A collective retirement model: Identification and estimation in the presence of externalities," IZA Discussion Papers, 1294.

Palumbo, M. (1999): "Uncertain medical expenses and precautionary saving near the end of the life cycle," Review of Economic Studies, 66, 395-421.

Vermeulen, F. (2002): “Collective household models: principles and main results," Journal of Economic Surveys, 16, 533-564.

Wallace, R.B. and A.R. Herzog (1995): "Overview of the Health Measures in the Health and Retirement Study,' Journal of Human Resources 30, 84-107. 
Table 1: Sample Statistics by Marital Status, 2005 and 2007 Waves of HRS/CAMS

\begin{tabular}{|c|c|c|c|c|c|c|}
\hline & $\begin{array}{c}\text { Widowed } \\
\text { Men }\end{array}$ & $\begin{array}{l}\text { Widowed } \\
\text { Women }\end{array}$ & $\begin{array}{c}\text { Single } \\
\text { Men }\end{array}$ & $\begin{array}{l}\text { Single } \\
\text { Women }\end{array}$ & $\begin{array}{c}\text { Married } \\
\text { Men }\end{array}$ & $\begin{array}{l}\text { Married } \\
\text { Women }\end{array}$ \\
\hline Age & $\begin{array}{c}68.9 \\
(5.74)\end{array}$ & $\begin{array}{c}68.8 \\
(6.89)\end{array}$ & $\begin{array}{c}64.5 \\
(7.61)\end{array}$ & $\begin{array}{c}65.9 \\
(7.81)\end{array}$ & $\begin{array}{c}66.7 \\
(6.87)\end{array}$ & $\begin{array}{c}63.7 \\
(7.06)\end{array}$ \\
\hline High school & 0.346 & 0.429 & 0.357 & 0.300 & 0.315 & 0.363 \\
\hline Some college & 0.212 & 0.244 & 0.343 & 0.320 & 0.240 & 0.284 \\
\hline College & 0.261 & 0.130 & 0.224 & 0.262 & 0.364 & 0.286 \\
\hline Good health & 0.729 & 0.779 & 0.718 & 0.699 & 0.857 & 0.870 \\
\hline Retired & 0.529 & 0.478 & 0.335 & 0.258 & 0.457 & 0.258 \\
\hline Female income contribution & & & & & \multicolumn{2}{|c|}{$(0.261)$} \\
\hline Observations & 79 & 420 & 223 & 387 & 1004 & 1004 \\
\hline
\end{tabular}

Notes: Mean and standard errors in parentheses. 
Table 2: Budget Shares by Marital Status, 2005 and 2007 Waves of HRS/CAMS

\begin{tabular}{lccccc}
\hline & $\begin{array}{c}\text { Widowed } \\
\text { Men }\end{array}$ & $\begin{array}{c}\text { Widowed } \\
\text { Women }\end{array}$ & $\begin{array}{c}\text { Single } \\
\text { Men }\end{array}$ & $\begin{array}{c}\text { Single } \\
\text { Women }\end{array}$ & $\begin{array}{c}\text { Married } \\
\text { Couples }\end{array}$ \\
\hline Groceries & 0.227 & 0.218 & 0.201 & 0.206 & 0.225 \\
Restaurant & 0.090 & 0.056 & 0.107 & 0.059 & 0.087 \\
Gasoline & 0.107 & 0.067 & 0.117 & 0.079 & 0.111 \\
Personal care & 0.018 & 0.041 & 0.025 & 0.042 & 0.034 \\
Clothing & 0.031 & 0.051 & 0.037 & 0.063 & 0.048 \\
Vacations & 0.078 & 0.067 & 0.068 & 0.074 & 0.131 \\
Utilities & 0.256 & 0.285 & 0.250 & 0.282 & 0.155 \\
Gardening & 0.016 & 0.043 & 0.023 & 0.032 & 0.032 \\
Car Maintenance & 0.034 & 0.038 & 0.048 & 0.042 & 0.040 \\
Home Maintenance & 0.143 & 0.133 & 0.124 & 0.119 & 0.138 \\
& & & & & \\
Observations & 79 & 420 & 223 & 387 & 1004 \\
\hline
\end{tabular}


Table 3: Budget Shares by Retirement Status for Married Couples, 2005 and 2007 Waves of HRS/CAMS

\begin{tabular}{lcccc}
\hline & $\begin{array}{c}\text { Husband } \\
\text { Not Retired }\end{array}$ & $\begin{array}{c}\text { Husband } \\
\text { Retired }\end{array}$ & $\begin{array}{c}\text { Wife } \\
\text { Not Retired }\end{array}$ & $\begin{array}{c}\text { Wife } \\
\text { Retired }\end{array}$ \\
\hline Groceries & 0.212 & 0.240 & 0.223 & 0.230 \\
Restaurant & 0.093 & 0.081 & 0.088 & 0.086 \\
Gasoline & 0.122 & 0.097 & 0.118 & 0.090 \\
Personal care & 0.034 & 0.033 & 0.035 & 0.030 \\
Clothing & 0.051 & 0.044 & 0.049 & 0.044 \\
Vacations & 0.124 & 0.141 & 0.125 & 0.149 \\
Utilities & 0.152 & 0.159 & 0.159 & 0.145 \\
Gardening & 0.029 & 0.035 & 0.028 & 0.041 \\
Car Maintenance & 0.042 & 0.037 & 0.040 & 0.039 \\
Home Maintenance & 0.141 & 0.134 & 0.135 & 0.145 \\
& & & & \\
Observations & 454 & 550 & 669 & 335 \\
\hline
\end{tabular}


Table 4: Budget Shares by Health Status for Married Couples, 2005 and 2007 Waves of HRS/CAMS

\begin{tabular}{lcccc}
\hline & $\begin{array}{c}\text { Husband in } \\
\text { Good Health }\end{array}$ & $\begin{array}{c}\text { Husband in } \\
\text { Poor Health }\end{array}$ & $\begin{array}{c}\text { Wife in } \\
\text { Good Health }\end{array}$ & $\begin{array}{c}\text { Wife in } \\
\text { Poor Health }\end{array}$ \\
\hline Groceries & 0.221 & 0.245 & 0.217 & 0.276 \\
Restaurant & 0.091 & 0.067 & 0.092 & 0.060 \\
Gasoline & 0.109 & 0.118 & 0.109 & 0.121 \\
Personal care & 0.033 & 0.038 & 0.034 & 0.033 \\
Clothing & 0.047 & 0.054 & 0.048 & 0.048 \\
Vacations & 0.135 & 0.111 & 0.141 & 0.069 \\
Utilities & 0.153 & 0.168 & 0.152 & 0.178 \\
Gardening & 0.031 & 0.034 & 0.032 & 0.029 \\
Car Maintenance & 0.040 & 0.038 & 0.039 & 0.047 \\
Home Maintenance & 0.139 & 0.127 & 0.137 & 0.139 \\
Observations & 839 & 165 & 863 & 141 \\
\hline
\end{tabular}


Table 5: Estimation Results: Scale Economies

Controls for Age, Controls for Education, Include all Medical Health, and Retirement Health, and Retirement Singles Expenditures

\section{Husband Scale Economy}

$\begin{array}{llllc}\text { Intercept } & -0.281^{*} & -0.333^{*} & -0.239^{*} & -0.230^{*} \\ & (0.010) & (0.035) & (0.007) & (0.059) \\ \text { Retirement } & 0.099^{*} & 0.044^{*} & 0.007^{*} & 0.004 \\ & (0.043) & (0.017) & (0.002) & (0.001) \\ \text { Poor health } & -0.086^{*} & -0.056^{*} & 0.002 & -0.023^{*} \\ & (0.029) & (0.019) & (0.006) & (0.005) \\ \text { Age } & 0.068^{*} & & -0.005 & -0.013 \\ & (0.030) & & (0.008) & (0.008)\end{array}$

Education $-0.087^{*}$

$(0.034)$

Wife Scale Economy

$\begin{array}{lcccc}\text { Intercept } & -0.497^{*} & -0.564^{*} & -0.371^{*} & -0.501^{*} \\ & (0.175) & (0.185) & (0.123) & (0.136) \\ \text { Retirement } & -0.019 & -0.210^{*} & 0.005 & 0.073 \\ & (0.010) & (0.098) & (0.003) & (0.376) \\ \text { Poor health } & -0.031 & -0.063^{*} & 0.076^{*} & 0.002^{*} \\ & (0.016) & (0.029) & (0.019) & (0.001) \\ \text { Age } & 0.037 & & 0.086 & -0.048 \\ & (0.012) & & (0.137) & (0.027) \\ \text { Education } & & -0.087^{*} & & \\ & & (0.022) & & \\ & & & & 1503 \\ \text { Observations } & 1503 & 1503 & 2113 & 144 \\ \text { of coefficients } & 132 & 132 & 132 & \end{array}$


Table 6: Estimation Results: Resource Shares

\begin{tabular}{|c|c|c|c|c|}
\hline & $\begin{array}{c}\text { Controls for Age, } \\
\text { Health, and Retirement }\end{array}$ & $\begin{array}{l}\text { Controls for Education, } \\
\text { Health, and Retirement }\end{array}$ & $\begin{array}{l}\text { Include all } \\
\text { Singles }\end{array}$ & $\begin{array}{c}\text { Medical } \\
\text { Expenditures }\end{array}$ \\
\hline \multirow[t]{2}{*}{ Intercept } & $0.333^{*}$ & $0.342^{*}$ & $0.306^{*}$ & $0.412^{*}$ \\
\hline & $(0.035)$ & $(0.037)$ & $(0.078)$ & $(0.117)$ \\
\hline \multirow[t]{2}{*}{ Income share of wife } & $0.004^{*}$ & $0.004^{*}$ & $0.008^{*}$ & 0.0008 \\
\hline & $(0.001)$ & $(0.002)$ & $(0.003)$ & $(0.0005)$ \\
\hline \multirow[t]{2}{*}{ Husband retired } & 0.018 & $-0.069^{*}$ & -0.0002 & $-0.031^{*}$ \\
\hline & $(0.027)$ & $(0.028)$ & $(0.0002)$ & $(0.008)$ \\
\hline \multirow[t]{2}{*}{ Wife retired } & 0.0005 & 0.030 & 0.0001 & -0.016 \\
\hline & $(0.029)$ & $(0.016)$ & $(0.0001)$ & $(0.034)$ \\
\hline \multirow[t]{2}{*}{ Husband in poor health } & $0.143^{*}$ & 0.027 & $0.013^{*}$ & 0.126 \\
\hline & $(0.052)$ & $(0.021)$ & $(0.003)$ & $(0.069)$ \\
\hline \multirow[t]{2}{*}{ Wife in poor health } & -0.046 & $-0.083^{*}$ & $-0.032^{*}$ & $-0.175^{*}$ \\
\hline & $(0.042)$ & $(0.033)$ & $(0.010)$ & $(0.055)$ \\
\hline \multirow[t]{2}{*}{ Husband's age } & $-0.007^{*}$ & & -0.004 & -0.001 \\
\hline & $(0.002)$ & & $(0.003)$ & $(0.002)$ \\
\hline \multirow[t]{2}{*}{ Wife's age } & $-0.008^{*}$ & & -0.003 & -0.001 \\
\hline & $(0.002)$ & & $(0.003)$ & $(0.003)$ \\
\hline \multirow[t]{2}{*}{ Husband's education } & & 0.002 & & \\
\hline & & $(0.008)$ & & \\
\hline \multirow[t]{2}{*}{ Wife's education } & & 0.002 & & \\
\hline & & $(0.008)$ & & \\
\hline Observations & 1503 & 1503 & 2113 & 1503 \\
\hline \# of coefficients & 132 & 132 & 132 & 144 \\
\hline
\end{tabular}




\section{RECENT WORKING PAPERS FROM THE}

\section{CENTER FOR RETIREMENT RESEARCH AT BOSTON COLLEGE}

Age Differences in Job Displacement, Job Search, and Reemployment

Richard W. Johnson and Corina Mommaerts, January 2011

The Earnings and Social Security Contributions of Documented and Undocumented Mexican Immigrants

Gary Burtless and Audrey Singer, January 2011

How Important Are Intergenerational Transfers for Baby Boomers?

Alicia H. Munnell, Anthony Webb, Zhenya Karamcheva, and Andrew Eschtruth, January 2011

Effect of Informal Care on Work, Wages, and Wealth

Courtney Harold Van Houtven, Norma B. Coe, and Meghan Skira, December 2010

Recessions, Wealth Destruction, and the Timing of Retirement

Barry P. Bosworth and Gary Burtless, December 2010

Measuring the Spillover to Disability Insurance Due to the Rise in the Full Retirement Age Norma B. Coe and Kelly Haverstick, December 2010

Is the Reduction in Older Workers' Job Tenure a Cause for Concern?

Steven A. Sass and Anthony Webb, December 2010

Accounting for Disability Insurance in the Dynamic Relationship Between Disability Onset and Earnings

Perry Singleton, November 2010

The Treatment of Married Women by the Social Security Retirement Program

Andrew G. Biggs, Gayle L. Reznik, and Nada O. Eissa, November 2010

What is the Impact of Foreclosures on Retirement Security?

Irena Dushi, Leora Friedberg, and Anthony Webb, November 2010

Children and Household Utility: Evidence from Kids Flying the Coop

Norma B. Coe and Anthony Webb, November 2010

Overview of the CRR 2009 Retirement Survey

Alicia H. Munnell, Norma B. Coe, Kelly Haverstick, and Steven A. Sass, October 2010

State Wage-Payment Laws, the Pension Protection Act of 2006, and 401(k) Saving Behavior

Gary V. Englehardt, October 2010

All working papers are available on the Center for Retirement Research website (http://crr.bc.edu) and can be requested by e-mail (crr@bc.edu) or phone (617-552-1762). 